\title{
Some Suggestions for Classification Criteria of Environmental and Health Hazards Based on the Investigation of Priority Hazardous Chemicals for Environmental Management in Sichuan Province
}

\author{
Airu Yue ${ }^{1, a}$, Qinghua Tian ${ }^{2, b}$ \\ ${ }^{1}$ Sichuan Province Environmental Protection Technology Engineering, China \\ ${ }^{2}$ Sichuan Academy of Environmental Science, China \\ a164330119@qq.com, b13032870811@163.com,
}

\begin{abstract}
Keywords: priority hazardous chemicals for environmental management; health hazard; environmental hazard; hazardous pressure classification

Abstract: Current situation of priority hazardous chemicals for environmental management in Sichuan province is investigated by reference to 84 priority hazardous chemicals for environmental management specified in the Measures for the Environmental Management Registration of Hazardous Chemicals Registration (Trial) issued by the Ministry of Environmental Protection of the People's Republic of China. One classification method of environmental and health hazardous pressure of priority hazardous chemicals for environmental management in Sichuan Province is proposed based on the investigation results. Meanwhile, priority prevention and control areas and industries of priority hazardous chemicals for environmental management in Sichuan Province are identified.
\end{abstract}

\section{Introduction}

Environmental management of hazardous chemicals, it refers to environmental management activities in allusion to the life-cycle of chemicals ${ }^{[1-2]}$. Its direct objective is to reduce and control health hazards and environmental release of hazardous and toxic chemicals to avoid environmental pollution and ecological damage. Chemicals sound management has become a major part of environmental management of various countries and one of the necessary means by which the human society achieves sustainable development ${ }^{[3]}$. In Oct. 2012, the Ministry of Environmental Protection of the People's Republic of China issued the Measures for the Environmental Management Registration of Hazardous Chemicals Registration (Trial) which specifies 84 priority hazardous chemicals for environmental management as management focuses ${ }^{[4]}$. This paper discusses environmental and health hazardous pressure classification of 84 priority hazardous chemicals for environmental management which could be found in Sichuan province based on their current situation investigation, and proposes guidance on the follow-up hazardous chemicals prevention and control scheme.

\section{Data and the Investigation}

The investigation is conducted based on data put on records in environmental protection, statistical, safety supervision, public security, etc. departments, industrial technological characteristics considered also. 3447 enterprises which might involve priority hazardous chemicals for environmental management are screened out throughout Sichuan Province, from which, 225 enterprises which involve priority hazardous chemicals are further screened out, which are engaged in 30 industries such as chemical raw material and chemical manufacturing and pharmaceutical manufacturing. 43 kinds of priority hazardous chemicals for environmental management are involved. The investigation made statistics on the annual amount of hazardous chemicals that involved totally and released. Total amount of PHCs (Priority Hazardous Chemicals) concludes the amount which involved in the manufacturing-transport-storage process. See Report ${ }^{[5]}$ for concrete results. Table 1 briefly shows some PHCs of the statistical results. 
Table 1 Total amount and release amount of priority hazardous chemicals in Sichuan province

\begin{tabular}{|c|c|c|c|c|c|c|c|}
\hline $\begin{array}{l}\mathrm{S} / \\
\mathrm{N}\end{array}$ & No. & $\begin{array}{c}\text { Chemical } \\
\text { name }\end{array}$ & Alias & $\begin{array}{l}\text { Total amount } \\
\text { (t/a) }\end{array}$ & $\begin{array}{c}\text { Product } \\
\text { aomount } \\
\text { (t/a) }\end{array}$ & $\begin{array}{c}\text { Residual } \\
\text { amount } \\
\text { (t/a) }\end{array}$ & $\begin{array}{c}\text { Release } \\
\text { amount } \\
(\mathrm{t} / \mathrm{a})\end{array}$ \\
\hline 1 & PHC001 & $\begin{array}{l}\text { 1,2,3-trichloro } \\
\text { benzene }\end{array}$ & $\begin{array}{l}\text { 1,2,3-trichloro-b } \\
\text { enzene }\end{array}$ & 40 & 40 & 0 & 0 \\
\hline 8 & PHC013 & Benzene & Pure benzene & 79082.69 & 77384.39 & 1299.57 & 398.72 \\
\hline 10 & PHC019 & $\begin{array}{c}\text { Crude } \\
\text { anthracene }\end{array}$ & & 1062 & 318.6 & 0 & I \\
\hline 12 & PHC022 & Naphthalene & $\begin{array}{l}\text { Crude } \\
\text { naphthalene; } \\
\text { refined } \\
\text { naphthalene; } \\
\text { naphthalene } \\
\text { cake }\end{array}$ & 27363.53 & 18355.93 & 400 & 8607.60 \\
\hline 15 & PHC034 & $\begin{array}{l}\text { Sodium } \\
\text { cyanide }\end{array}$ & Cyanide & 22362.66 & 19930.01 & 721.73 & 1710.92 \\
\hline
\end{tabular}

Generally, priority hazardous chemicals subject to enterprise annual output, sales volume and usage amount over 1,000 tons are: PHC058 of sodium bichromate (79129.32t/a), PHC013 of benzene (79082.69t/a), PHC059 of chromium trioxide [anhydrous] (42193.91t/a), PHC022 of naphthalene (27363.53t/a), PHC034 of sodium cyanide (22362.66t/a), PHC057 of potassium dichromate (4140.01t/a), PHC019 of crude anthracene (1062t/a). The enterprises cause environmental hazards to a certain extent in the course of production, distribution and consumption of hazardous chemicals; hazardous chemicals subject to amount of release into environment of over 1 million tons are: PHC022 of naphthalene (8607.60t/a), PHC058 of sodium bichromate (3100.07t/a), PHC034 of sodium cyanide (1710.92t/a), PHC020 of ethylene oxide (892.68t/a), PHC013 of benzene (398.72t/a), PHC048 of mercury bichloride (324.48t/a), and PHC059 of chromium trioxide [anhydrous] (211.63t/a). The release of hazardous chemicals in the course of consumption could cause health safety problems against surrounding residents.

Meanwhile, the investigation is directed against priority hazardous chemicals involved by industrial enterprises in Sichuan Province. Analysis of the industries which have the largest total amount of each kind of priority hazardous chemical and use information is made. See the Report ${ }^{[5]}$ for concrete results. Table 2 briefly shows some PHCs of the results.

Table 2 Industries categories with the largest total amount and release amount of priority hazardous chemicals in Sichuan province

\begin{tabular}{|c|c|c|c|c|}
\hline $\begin{array}{l}\mathrm{S} / \\
\mathrm{N}\end{array}$ & No. & $\begin{array}{l}\text { Chemical } \\
\text { name }\end{array}$ & $\begin{array}{c}\text { Statistics of enterprises with the largest total } \\
\text { amount } \\
\text { Industry category }\end{array}$ & $\begin{array}{c}\text { Statistics of enterprises with the } \\
\text { largest release amount } \\
\text { Industry category }\end{array}$ \\
\hline 1 & PHC001 & $\begin{array}{l}\text { 1,2,3-trichloro } \\
\text { benzene }\end{array}$ & $\begin{array}{l}\text { Chemical raw material and chemicals } \\
\text { manufacturing industry }\end{array}$ & / \\
\hline 8 & PHC013 & Benzene & $\begin{array}{c}\text { Petroleum processing, coking, and nuclear } \\
\text { fuel processing }\end{array}$ & $\begin{array}{l}\text { Chemical raw material and } \\
\text { chemicals manufacturing } \\
\text { industry }\end{array}$ \\
\hline 10 & PHC019 & $\begin{array}{l}\text { Crude } \\
\text { anthracene }\end{array}$ & $\begin{array}{c}\text { Petroleum processing, coking, and nuclear } \\
\text { fuel processing }\end{array}$ & $\begin{array}{l}\text { Sales after purification by the } \\
\text { enterprise, statistics of release } \\
\text { amount not made }\end{array}$ \\
\hline 12 & PHC022 & Naphthalene & $\begin{array}{c}\text { Petroleum processing, coking, and nuclear } \\
\text { fuel processing }\end{array}$ & $\begin{array}{l}\text { Chemical raw material and } \\
\text { chemicals manufacturing } \\
\text { industry }\end{array}$ \\
\hline 15 & PHC034 & $\begin{array}{l}\text { Sodium } \\
\text { cyanide }\end{array}$ & Nonferrous metals mining and dressing & $\begin{array}{l}\text { Nonferrous metals mining and } \\
\text { dressing }\end{array}$ \\
\hline
\end{tabular}

Industries with the largest total amount of various priority hazardous chemicals include the chemical raw material and chemicals manufacturing industry (21 priority hazardous chemicals), pharmaceutical industry (8 priority hazardous chemicals), petroleum processing, coking, and 
nuclear fuel processing (3 priority hazardous chemicals); industries with the largest release amount of various priority hazardous chemicals include chemical raw material and chemicals manufacturing industry (16 priority hazardous chemicals), pharmaceutical industry (10 priority hazardous chemicals), and general-purpose equipment manufacturing (2 priority hazardous chemicals).

\section{The Classification Criteria of Hazardous Pressure}

\subsection{Health hazardous pressure classification}

To consult the Globally Harmonized System of Classification and Labelling of Chemicals (GHS), global chemicals health hazards mainly include ten categories, namely toxicity, corrosion, irritation, sensitization, carcinogenicity, germ cell mutagenicity, reproductive toxicity, specific target organ toxicity (single exposure), specific target organ toxicity (repeated exposure), and aspiration toxicity ${ }^{[6]}$. According to the preliminary investigation and statistics, health hazards of priority hazardous chemicals for environmental management are mainly toxicity, irritation, sensitization, corrosion, and carcinogenicity. On the basis of toxicology, damage caused by chemicals on organism refers to changes in the biochemistry which affects organism behavior, dysfunction or pathological damage, or reduction in the stress reaction capacity against the imposed environment. After the organism was exposed to chemicals, health hazardous result depends on the properties and dosage of chemicals. Chemicals could cause many lesions, which is called the spectrum of toxic effects, which may be manifested as load increase of the organism against chemicals, equivocal physiological and biochemical index change, subclinical change, clinical intoxication, and death ${ }^{[7]}$. Evaluation basis of health hazard classification in this paper is the result of toxic effect on human body.

According to investigation results ${ }^{[5]}$, purposes and dosages of priority hazardous chemicals for environmental management in Sichuan Province used by relevant enterprises are different, and total annual amount of hazardous chemicals range from $5 \times 10^{-5}$ t to $7 \times 10^{4} \mathrm{t}$. To better evaluate and analyze the current situation of hazardous chemicals heath hazard pressure, this paper divides five dosage ranges of total annual amount of hazardous chemical by over 5000t, 1000-5000t, 100-1000t, 10-100t, and less than 10t.

By reference to the Database of Priority Hazardous Chemicals for Environmental Management ${ }^{[5]}$, toxic effect results are divided into very serious, serious and moderate, the lethal toxic effect result is very serious; clinic toxicity and carcinogenicity toxic effect result is serious, and the irritation and sensitization toxic effect result is moderate; toxic effect result of hazardous chemicals whose health hazards are not yet clear shall be considered as serious.

To combination with the toxic effect results of hazardous chemicals listed in the Database of Priority Hazardous Chemicals for Environmental Management ${ }^{[5]}$ and total amount of priority hazardous chemicals, classification criteria of pressure current situation of health hazards of priority hazardous chemicals are shown in Table 3.

Table 3 Classification criteria for health pressure current situation of priority hazardous chemicals

\begin{tabular}{ccc}
\hline $\begin{array}{c}\text { Total amount of priority } \\
\text { hazardous chemical }(\mathrm{t})\end{array}$ & $\begin{array}{c}\text { Toxic effect result of priority } \\
\text { hazardous chemical }\end{array}$ & $\begin{array}{c}\text { Pressure grade of health hazard of priority } \\
\text { hazardous chemical }\end{array}$ \\
\hline & Very serious & Grade I \\
Above 5000 & Serious & Grade I \\
& Moderate & Grade I \\
& Very serious & Grade I \\
$1000 \sim 5000$ & Serious & Grade II \\
& Moderate & Grade I \\
& Very serious & Grade II \\
$100 \sim 1000$ & Serious & Grade III \\
& Moderate & Grade II \\
$10 \sim 100$ & Very serious & Grade II \\
\end{tabular}




\begin{tabular}{ccc}
\hline $\begin{array}{c}\text { Total amount of priority } \\
\text { hazardous chemical }(\mathrm{t})\end{array}$ & $\begin{array}{c}\text { Toxic effect result of priority } \\
\text { hazardous chemical }\end{array}$ & $\begin{array}{c}\text { Pressure grade of health hazard of priority } \\
\text { hazardous chemical }\end{array}$ \\
\hline \multirow{2}{*}{ Less than 10} & Very serious & Grade II \\
& Serious & Grade III \\
Moderate & Grade III \\
\hline
\end{tabular}

Based on the classification criteria given in Table 3, taking total amount of priority hazardous chemicals in consideration, health pressure of 43 priority hazardous chemicals in Sichuan Province has been detected. For example, toxic effect of PHC022 of naphthalene is investigated to be clinic toxicity, which means that the toxic effect result is serious. To check statistics shown in Table 1, total annual amount of naphthalene of enterprises in Sichuan Province is 27363.53t. According to the classification criteria, health hazard of naphthalene is Grade I. Table 4 shows the result of Naphthalene classification.

Table 4 Classification results of health hazards of partial priority hazardous chemicals in Sichuan Province

\begin{tabular}{cccccc}
\hline S/N & PHC No. & $\begin{array}{c}\text { Chemical } \\
\text { name }\end{array}$ & $\begin{array}{c}\text { Release amount } \\
(\mathrm{t} / \mathrm{a})\end{array}$ & $\begin{array}{c}\text { Spectrum of toxic effects result } \\
\text { of priority hazardous chemical }\end{array}$ & $\begin{array}{c}\text { Pressure grade of health hazard } \\
\text { of priority hazardous chemical }\end{array}$ \\
\hline 12 & PHC022 & Naphthalene & 27363.53 & Serious & Grade I \\
\hline
\end{tabular}

Comparing results with Table 2, it is obvious that PHC022 of naphthalene, a kind of hazardous chemical with health hazard grade of Grade I, mainly exists in the petroleum processing, coking, and nuclear fuel processing industry.

By reference to this classification method that proposed above, health hazardous pressure of 43 hazardous chemicals in Sichuan Province can be detected and corresponding industrial distribution can be identified.

3.2 Environmental hazardous pressure classification

To consult GHS, global chemicals environmental hazards mainly include water pollution and ozone pollution [6]. However, the Database of Directory, Characteristics and Properties of Priority Hazardous Chemicals for Environmental Management which is established based on data collected in many ways only provides clear environmental hazard information of 56 kinds of chemicals. As a result, referring to the Analyses and Assessment on Environmental Risks of Hazardous Chemical in Petrochemical Industry in China ${ }^{[8]}$ and Overall Design of Technical Specification for Risk Source Monitoring of Major Environmental Pollution Event ${ }^{[9]}$, types and effects of major accidents maybe take place for various hazardous chemicals are shown in Table 5.

\begin{tabular}{cc}
\multicolumn{1}{c}{ Table 5} & Types and effects of environmental risk accidents \\
\hline S/N & Accident effect type \\
\hline 1 & Ignition, combustion and smog affecting the environment \\
2 & Leakage into water causing losses \\
3 & Explosive vibration causing off-site environmental losses \\
4 & Explosion fragments flying off the plant causing environmental losses \\
5 & Environmental pollution caused by poison gas leakage causing losses \\
\hline
\end{tabular}

Note: Possibility sorting of environmental risk accidents: $1>2>3>4>5$; seriousness sorting: $5>4>3>2>1$.

Shown in Table 5, by reference to the Database of Priority Hazardous Chemicals for Environmental Management, environmental risks of priority hazardous chemicals are divided into high and low. Among environmental risk accidents, fire, overflow and explosion accidents as well as toxic substance leakage accidents with serious consequences, which are most probable, are considered as having a high-risk, and others are considered as having a low-risk; priority hazardous chemicals with unknown environmental hazards are considered as having a high-risk.

According to investigation results, purposes of priority hazardous chemicals for environmental management in Sichuan Province used by different enterprises are not similar, and dosages not equal, and annual release amount of hazardous chemicals range from $3 \times 10^{-5} t$ to $8 \times 10^{3} t$. To better evaluate and analyze the current situation of hazardous chemicals environmental hazardous pressure, this paper divides five dosage ranges of annual release amount of hazardous chemical by over 1000t, 100-1000t, 10-100t, 1-10t, and less than $1 t$. 
By referring to the Database of Directory, Characteristics and Properties of Priority Hazardous Chemicals for Environmental Management, classification criteria for pressure current situation of environmental hazards of priority hazardous chemicals are as follows:

\section{Table 6 Pressure classification Criteria for environmental hazards of priority hazardous} chemicals

\begin{tabular}{ccc}
\hline $\begin{array}{c}\text { Release amount of priority } \\
\text { hazardous chemical }(\mathrm{t})\end{array}$ & $\begin{array}{c}\text { Environmental risk of priority } \\
\text { hazardous chemicals }\end{array}$ & $\begin{array}{c}\text { Pressure grade of environmental hazards of } \\
\text { priority hazardous chemical }\end{array}$ \\
\hline Above 1000 & High & Grade I \\
& Low & Grade I \\
$100 \sim 1000$ & High & Grade I \\
& Low & Grade II \\
$10 \sim 100$ & High & Grade II \\
& Low & Grade II \\
$1 \sim 10$ & High & Grade II \\
& Low & Grade III \\
Less than 1 & High & Grade III \\
\hline
\end{tabular}

To combination of the classification criteria given in Table 6 and release amount of priority hazardous chemicals, environmental hazards pressure of 43 priority hazardous chemicals in Sichuan Province is detected. For example, major accident type of PHC022 of naphthalene is investigated to be fire, which means that the environmental risk is high. To check statistics in Table 1, total annual release amount of naphthalene of enterprises in Sichuan Province is 8607.60t. According to the classification criteria, health hazard of naphthalene is Grade I, shown in Table 7.

Table 7 Classification results of environmental hazard pressure of priority hazardous chemicals

\begin{tabular}{|c|c|c|c|c|c|}
\hline $\begin{array}{l}\mathbf{S} / \\
\mathbf{N}\end{array}$ & $\begin{array}{l}\text { PHC } \\
\text { No. }\end{array}$ & $\begin{array}{l}\text { Chemic } \\
\text { al name }\end{array}$ & $\begin{array}{c}\text { Release } \\
\text { amount } \\
\text { (t/a) }\end{array}$ & $\begin{array}{l}\text { Risk of priority hazardous } \\
\text { chemicals }\end{array}$ & $\begin{array}{c}\text { Pressure grade of environmental hazards of priority } \\
\text { hazardous chemical }\end{array}$ \\
\hline 12 & $\begin{array}{c}\text { PHC0 } \\
22\end{array}$ & $\begin{array}{l}\text { Naphthal } \\
\text { ene }\end{array}$ & 8607.60 & High & Grade I \\
\hline
\end{tabular}

By comparing results with Table 2, it is obvious that PHC022 of naphthalene, a kind of hazardous chemical with health hazard grade of Grade I, mainly exists in the chemical raw material and chemicals manufacturing industry.

By reference to this classification method, environmental hazard pressure of 43 hazardous chemicals in Sichuan Province can be detected and corresponding industrial distribution can be identified.

\section{Conclusion}

Based on the classification method proposed above, enterprises in Province Sichuan involved in priority hazardous chemicals for environmental management are identified in terms of health and environmental hazard pressure. The conclusion is that chemical raw material and chemicals manufacturing industry, nonferrous metals mining and dressing industry are industries with extremely high health hazard grade; chemical raw material and chemicals manufacturing industry, nonferrous metals mining and dressing industry, chemical fiber manufacturing industry, and petroleum processing, coking, and nuclear fuel processing industries are industries with extremely high environmental hazard. Meanwhile, applied the investigation results and the classification criteria further, cities in Province Sichuan subject to large priority hazardous chemicals-related health and environmental hazardous pressure mainly centralized in the Chengdu-Deyang-Mianyang Industrial Cooperation Belt, old industrial regions in four cities in southern Sichuan and Panzhihua-Xichang Economic Zone. Relevant departments of Sichuan Province may, based on the above conclusion, delimit priority hazardous chemicals-related priority preventation and control areas, industries, and enterprises in Sichuan, established the information database of priority hazardous chemicals in Province Sichuan to support focused supervision by environmental protection departments at all levels. 
However, classification criteria given hereinabove are only based on the investigation results of current situation of priority hazardous chemicals for environmental management in Province Sichuan. As far as the classification methods are concerned, range of total amount and release amount of hazardous chemicals is limited by the scope of investigation. If the scope of investigation was more comprehensive, the range of total amount and release amount of hazardous chemical should change, and classification criteria adjusted simultaneously. In this paper, health and environmental hazardous pressure of hazardous chemicals is ranked in three grades which seems not rigorous enough. Then, relevant departments should establish the prevention and control strategy and response grade of hazardous chemicals, classification criteria given hereinabove might be adjusted properly to cooperate with management over hazardous chemicals.

\section{References:}

[1] Ge Haihong. Latest Implementation Progress of Strategic Approach to International Chemicals Management (SAICM) and Countermeasures and Suggestions [J], Modern Chemical Industry, 2014, 34(6):1-4, 6, In Chinese

[2] IPCS. Key Elements of a National Programme for Chemicals Management and Safety http://www2.unitar.org/cwm/publications/cw/inp/key_elements.pdf

[3] UNEP/WHO. Strategic approach to international chemicals management [OL]. [2014-04-11]. http://www.saicm.org /index.php

[4] Notice of the Ministry of Environmental Protection of the People's Republic of China on Issuing the Catalog of Priority Hazardous Chemicals for Environmental Management. http://www.zhb.gov.cn/gkml/hbb/bgt/201404/W020140409515213059460.pdf

[5] Yue Airu, Wang Wei, Tian Qinghua, et al. Investigation Report of Current Situation of Priority Hazardous Chemicals for Environmental Management in Sichuan Province. Sichuan Academy of Environmental Sciences. Sept. 2015, In Chinese

[6] UN. Globally Harmonized System of Classification and Labelling of Chemicals. Third Revised Edition [Z], 2013.

[7] Zhou Zongcan, Fu Lijie. Modern Toxicology: A Concise Course [M]. Military Medical Science Press, 2012, In Chinese

[8] Li Yunyan, Guo Jianzhu. Analyses and Assessment on Environmental Risks of Hazardous Chemical in Petrochemical Industry in China [J] Shanghai Environmental Sciences, 2013, 32(2): 52-56, In Chinese

[9] Wen Lili, Yu Bofan, Xu Weining, et al. Overall Design of Technical Specification for Risk Source Monitoring of Major Environmental Pollution Event [J] Research of Environmental Sciences, 2011, 24(3): 347-353, In Chinese 